Improving Profitability Forecasts with Information on Earnings Quality

Matthias Demmer

School of Business \& Economics

Discussion Paper

FACTS

$2015 / 16$ 


\title{
Improving Profitability Forecasts with Information on Earnings Quality
}

\author{
Matthias Demmer \\ Ph.D. Candidate \\ Freie Universität Berlin \\ matthias.demmer@fu-berlin.de
}

May 2015

\begin{abstract}
Prior literature documents the usefulness of the DuPont disaggregation for predicting firms' future profitability, operating income, and stock market returns. In addition, research also emphasizes the importance of earnings quality information. However, there is a lack of research examining how earnings quality affects forecasts of profitability. This paper explores whether different earnings quality factors moderate the accuracy of profitability forecasts. This study contributes to the existing literature along three dimensions. First, contrary to financial statement analysis studies, I find that changes in profit margin provide incremental information for predicting changes in future return on assets. After controlling for earnings quality factors, the incremental usefulness of this accounting signal increases significantly. Second, this paper contributes to the earnings quality literature by providing an approach as how to include this information into forecasts of profitability. In doing so, I incorporate the main drivers of earnings quality (i.e. fundamental performance and the accounting system) into profitability forecasts. Last, the paper adds to the literature on how capital market participants perceive accounting information. I document that both analysts and investors appear to efficiently incorporate earnings quality information in their investment decisions.
\end{abstract}

JEL classification: M41

Keywords: Financial Statement Analysis, Forecasting Profitability, DuPont Analysis, Earnings Quality, Conservative Accounting, Persistence, Growth, Return on Net Operating Assets 


\section{Introduction}

Research on financial statement analysis (FSA) documents the usefulness of accounting information predicting firms' future profitability (Ou and Penman [1989]; Ou [1990]; Abarbanell and Bushee [1997]; Fairfield and Yohn [2001]; Fairfield et al. [2003]). Research on earnings quality concludes that accounting information is dependent on firm's fundamental performance and its accounting system (Ball and Shivakumar [2005]; Dechow et al. [2010]). While prior work separately emphasizes the importance of FSA and earnings quality for informing external recipients of financial statements about firms' financial and operational performance, considerably less is known how earnings quality impacts the accuracy of FSA models.

In predicting future performance, textbooks and research suggest a variety of parsimonious variables that improve the predictability of future performance. Fairfield and Yohn [2001] and Soliman [2008] present evidence that ratio analysis, that systematically breaks down profitability (RNOA) into more specific ratios according to the DuPont disaggregation, provides incremental information on accounting signals studied in prior research. Despite the popular appeal of such forecast models, prior research overlooks that accounting information flowing into forecast models might be exposed to changes in firms' earnings quality. This shift could bias profitability ratios and consequently impair the accuracy of forecasts. My study probes the extent to which the accuracy of FSA forecast models can be explained by the quality of reported earnings. In other words, I unite distinct findings of two previously separate literature streams to investigate whether joint consideration improves predictions of firms' profitability.

I begin my empirical analysis by examining the relative importance of earnings quality in explaining one-year-ahead profitability changes. I document that the earnings quality 
information leads, in contrast to standard DuPont disaggregation, to higher in-sample explanatory power of one-year-ahead changes in RNOA and DuPont components. Contrary to previous findings, the change in profit margin seems to possess relative usefulness. My findings imply that disaggregated DuPont components are partially influenced by the quality of firms' reported earnings. In order to avoid inaccurate conclusions from time invariant in-sample parameter estimations for the accuracy of the forecast model (Poon and Granger [2003]), the paper also shows evidence in out-of-sample predictions as suggested by Lev et al. [2010]. I find that earnings quality enhanced forecast models are incrementally informative in predicting changes in year-ahead RNOA. I also find a statistically significant relation between earnings quality and forecast errors from DuPont prediction models.

The second part of this study addresses how earnings quality is reflected in market expectations of firm performance. Specifically, I investigate the behavior of two groups of market participants: analysts and investors. I find that analysts' forecasts are more closely related to earnings quality enhanced prediction models than to standard DuPont disaggregation models. Likewise, investors appear to efficiently incorporate earnings quality information into stock prices. Year-ahead returns from hedge portfolios that are formed by a simple trading heuristic, using the competing models of traditional and earnings quality enhanced profitability forecasts, do not yield excess returns.

I also conduct a number of additional analyses and robustness checks. I evaluate the relative improvement in forecast accuracy by using industry specific models (two-digit and four-digit SIC codes) and find no improvement in line with Fairfield et al. [2009]. I also compare the forecast accuracy of five year rolling regressions with annual cross-sectional regressions. I find no significant difference in performance.

My study makes several important contributions to the literature on forecasting with accounting ratios and earnings quality. First, I extend the literature on forecasting profitability 
in several ways. I demonstrate the incremental accuracy of earnings quality enhanced forecast models for future changes in profitability in-sample and out-of-sample. I show that changes in profit margin, in particular, are sensitive to changes in firms' earnings quality. Furthermore, I contribute to the FSA research more generally by showing that the change in profit margin has become incrementally useful for predicting year-ahead changes in RNOA over the last decade.

I also contribute to the earnings quality literature by investigating the association between changes in firms' earnings quality and forecast accuracy. I highlight how components, which partially capture the effect of the accounting system and firms' performance on earnings quality, can be operationalized into forecasts. I further confirm findings of Rajan et al. [2007] that growth and conservatism are substitutes for predicting future profitability. Last, my findings suggest that market participants efficiently use earnings quality information for making investment decisions. My results also have implications for the econometrical design of forecast models. Rolling regression models do not appear to be superior to forecasts that use annual cross-sectional regressions.

I organize the remainder of this study as follows: section 2 provides motivation, discusses prior literature and develops my hypotheses. Section 3 describes variable construction and the data sample. Section 4 presents empirical results and Section 5 contains robustness checks. Section 6 concludes.

\section{Related literature and research question}

2.1. Forecasting profitability in the FSA literature

Earlier research shows that FSA is useful in various contexts. Penman [2010] broadly partitions FSA research into three types: risk determination, valuation, and financial forecasting. Risk analysis encompasses the prediction of default probabilities (Campbell et al. [2008]; Beaver et al. [2012]) and takeovers (Raman [2013]), credit ratings (Blume et al. [1998]; 
Kim et al. [2013]) or the estimation of firms' risk premium (Nekrasov and Shroff [2009]). The objective of the valuation literature is to convert financial ratios into firm value (e.g. Nissim and Penman [2001]; Barth et al. [2005]). Profitability forecasting uses ratios to estimate future performance in terms of earnings (Fairfield et al. [1996]), cash-flows (Barth et al. [2015]) or stock returns (Mohanram [2005]; Piotroski and So [2012]).

The early ratio-based forecast models generally used a wide range of accounting data in an unstructured way (e.g. Ou and Penman [1989]; Lev and Thiagarajan [1993]; Setiono and Strong [1998]). The more recent accounting literature uses valuation frameworks to set up forecast models in stepwise manner. In this vein, DuPont analysis is used to disaggregate profitability in a structured way. It decomposes profitability, defined as return on net operating assets (RNOA), into profit margin (PM) and asset turnover (ATO):

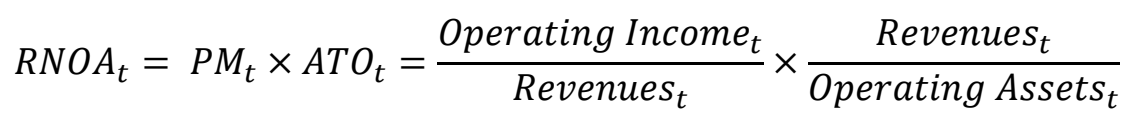

Beyond that, one can further disaggregate ATO and PM into its components so that profitability is dissected to provide more information about the composition of firms' overall profitability. This paper concentrates on the ability of PM and ATO to predict future profitability. PM captures the impact of sales on firms' profit or, in other words, the operating efficiency. ATO measures sales per the employed amount of operating assets, so how efficiently a firm uses its assets. By analyzing both components, one can reveal how efficiently revenues were generated by the assets and how the costs are controlled during this value creation process.

Research has documented the explanatory power of the DuPont disaggregation for both explaining current levels of profitability as well as for forecasting future profitability. By showing the association between equity value and profitability (RNOA) in the residual income valuation model, Nissim and Penman [2001] highlight how an understanding of the trend and 
persistence of RNOA and its components assists with valuation and forecasting. Fairfield and Yohn [2001] provide evidence that the DuPont disaggregation provides incremental information for estimating one-year-ahead changes in RNOA. Soliman [2008] finds that analysts and investors do not fully impound the predictive information of PM and ATO in their decision making. Amir et al. [2011] differentiate between conditional (power of a DuPont ratio's persistence to explain the persistence of a variable higher up in the DuPont hierarchy) and unconditional persistence (measured as the first-order autocorrelation coefficient) of DuPont ratios and find that RNOA components exhibit varyingly conditional and unconditional persistence. Furthermore, they find that the market's reaction to PM is stronger than to ATO. Lately, Baik et al. [2013] use frontier analysis to demonstrate that operational efficiency (measured as ATO) is useful in predicting firm performance.

2.2. Earnings quality and the influence on profitability forecasts

Earnings are said to be of higher quality when they provide more information about the features of a firm's financial performance for decision making (Dechow et al. [2010]). Earnings quality thereby depends on the specific situation. This makes the term earnings quality conditional on the frame of reference. Even though a vast stream of accounting research on earnings quality demonstrates its consequences, for instance, on stock prices and returns (Callen et al. [2013]), cost of capital (Francis et al. [2008]), or information asymmetry (Bhattacharya et al. [2013]), little is known of how earnings quality impacts the forecast accuracy of ratio-based forecast models.

Earnings quality is jointly determined by both the accounting system and by the firm's fundamental performance (Barth et al. [2008]). Accordingly, if a firm experiences a change, either in its operating profitability or in its accounting system, it might also have an impact on 
earnings quality or, as a result, on the accuracy of an earnings forecast model. By omitting one of these partly joint earnings quality determinants, forecast models might lose information which lowers the explanatory power.

Previous forecast models in the FSA literature predominantly focus on firms' performance without considering the influence of the accounting system. However, the earnings quality literature presents growing evidence that firm performance and the accounting system both affect future profitability and market reactions. For example, Lipe [1986] and Sloan [1996] find differences in the persistence of earnings components, suggesting that forecasts should weigh the influence of each component differently. Amir et al. [2011] provide evidence that the market reacts differently to the conditional and unconditional persistence of DuPont ratios.

Another approach analyzing the impact of earnings quality on firms' future profitability is the examination of the total magnitude of accruals or the error term from regressing accruals on their economic drivers. Xie [2001] observes that non-discretionary accruals have more predictive ability than residuals from the Jones [1991] model for explaining one-year-ahead earnings. Dechow and Dichev [2002] conclude that accrual quality is positively related with earning quality proxies. These studies suggest that an extreme magnitude of accruals decreases earnings persistence and, ultimately, forecast accuracy. To this extent, Tucker and Zarowin [2006] find that firms which actively manage the smoothness of earnings (firms with a stronger negative correlation between discretionary accruals and earnings) provide earnings with more information about future earnings.

A further group of studies on earnings quality examines the consequences of the accounting system. Research investigates how the selection of accounting principles impacts the quality of accounting numbers disclosed in firms' financial statements. In this vein, great effort has been undertaken to understand the impact of conservative accounting on earnings 
and profitability ratios. Conservatism is broadly interpreted as the choice of accounting treatments that are likely to understate net assets and cumulative income (e.g. Revsine et al. [2005]). More recent research distinguishes between unconditional and conditional conservatism. Unconditional conservatism reflects the application of conservative accounting policies (e.g. expenditure of R\&D and advertising) whereas conditional conservatism is eventdriven (e.g. different timeliness of recognizing towards unfavorable information faster than towards favorable information; Beaver and Ryan [2005]). Normative and empirical research examine how the joint influence of conservative accounting and growth in investments affect earnings quality. Under conservative accounting, firms build reserves and understate their reported earnings when investments in operating assets increase. In contrast, if investments decrease, built reserves could get released. Either way, changes in growth under conservative accounting affect earnings quality due to earnings becoming temporarily bloated or inflated. Ignoring these changes could consequently distort forecasts which naively fixate on earnings as reported in the financial statements. Beaver and Ryan [2000] find that the association of conservatism in combination with growth and future book return on equity is less negative for firms with higher investments. Penman and Zhang [2002] develop a diagnostic measure that captures the joint effect of conservative accounting and growth on earnings quality. The diagnostic measure predicts differences of firms' future profitability and stock returns, indicating the usefulness of information on earnings quality in forecast models. Rajan et al. [2007] analytically and empirically investigate the joint effect of conservatism and growth on return on investments (ROI). Explaining the joint impact of both variables on future ROI, they find that these two variables are substitutes. They argue that, under conservative accounting, growth not only tends to lower ROI, but also initiates a downward effect where more conservatism further magnifies this joint effect. This contradicts previous beliefs regarding how conservatism and growth interact. 
These earnings quality studies have documented an association between firm performance and the application of accounting principles on the one side, and their explanatory power for future earnings on the other side. However, there still exist certain caveats for transferring this knowledge into profitability forecast models. First, previous research on earnings quality is more fixated on revealing accounting anomalies that were not perceived by market participants rather than on developing an understanding of how earnings quality affects future profitability. As a result, the earnings quality literature and the FSA literature were often treated as detached research areas. Fundamental analysis investigates how an analysis of firm performance provides information about future profitability. Earnings quality studies investigate how the accounting choices and the quality of accounting performance indicators, as disclosed in firms' financial statements, provide information about future profitability. This paper attempts to bridge the gap between these parallel research areas by analyzing how the creation of firm performance interacts with the measurement quality of accounting profitability.

Second, the previous literature generally does not discern between accounting information and external sources of information when developing forecast models. ${ }^{1}$ In comparison to the accounting anomaly literature that uses both accounting information and market information in forecasts, I constrain the information set purely to balance sheet and income statement items. By using a closed accounting model without external influences such as market expectations, I mainly reduce the influencing factors on forecasts' accuracy to firm performance and earnings quality.

Third, there is mixed evidence on whether the joint impact of conservatism and growth provides explanatory power for future profitability (Penman and Zhang [2002]), or whether

\footnotetext{
${ }^{1}$ Mohanram [2005], among other studies, is an example how FSA literature does not clearly separate accounting and market information. Even though some papers enhance forecast models with proxies for earnings quality, influences from other proxies prevent drawing conclusion on the distinct influence of earnings quality on profitability forecasts.
} 
they are substitutes (Rajan et al. [2007]). Although the valuation literature emphasizes the influence of monopoly returns as they occur from firms' ability to sustain abnormal earnings relative to its market peers, there is no evidence as to whether past persistence enhances the predictability of future returns. I provide evidence that the persistence of different profitability components helps to explain future RNOA.

Drawing on previous literature, I try to capture the impact of earnings quality with two proxies. The first proxy captures earnings quality that originates from the fundamental performance of a firm. This proxy enhances the fundamental ratios from the DuPont disaggregation to explain fundamental firm performance in more detail. I assume that firms with more stable profitability also disclose earnings of higher quality since the variance of reported earnings decreases which facilitates the prediction of future earnings. Under this assumption, the paper uses the persistence of fundamental performance as a proxy for earnings quality. But the persistence of profitability also depends on the accounting measurement system. In order to overcome this shortcoming, the paper adds a second proxy for the influence of the accounting system on earnings quality. I discuss the proxy for the accounting system in section 3.1 in more detail. This way, I cover two main components of earnings quality, the influence of the firm performance and of the accounting system.

I address the influence of earnings quality on profitability forecasts ( $\Delta$ Future Profitability) by expanding a traditional ratio-based forecast model (FSA-Model) with earnings quality $(E Q)$ of firms' performance and the accounting system:

$\Delta$ Future Profitability $=f($ FSA-Model $\mid E Q)$ 
The prediction of future changes in profitability thus becomes a function of a FSA forecast model using traditional DuPont disaggregation and proxies for earnings quality which capture the effects of changes in firms' performance and effects of changes in the accounting system. ${ }^{2}$

Taken together, prior literature shows that forecasts based on accounting numbers, and DuPont analysis in particular, are useful for predicting future profitability and market reactions. Another strand of literature emphasizes the impact of earnings quality on historical and future profitability. By comparing the in-sample explanatory power and out-of-sample forecast errors from traditional forecasts against earnings quality enhanced forecasts, I provide empirical evidence on the incremental usefulness of each factor.

\subsection{Hypothesis development}

FSA literature has shown the usefulness of accounting information for the prediction of future profitability (Fairfield and Yohn [2001]; Soliman [2008]). The earnings quality literature has shown the impact of performance and accounting system related influences on future profitability (Dechow et al. [2010]). But impacts from both factors were analyzed separately. Furthermore, the previous literature did not separately distinguish between pure accounting information and additional external information. So ex ante, the impact of earnings quality on accounting profitability forecast models is not clear. This leads to the first hypothesis in the null form:

H1: Information on earnings quality in accounting forecast models does not provide additional explanatory power about firms' future profitability.

\footnotetext{
${ }^{2}$ Drawing on findings from Fairfield and Yohn [2001] who find that DuPont components are only useful for predicting the future change in profitability but not the level, I focus my research on year-ahead changes in profitability.
} 
In this context, the next question that naturally rises is whether profitability forecasts complemented with information on earnings quality could improve traditional forecast models. Improvements would mean that earnings quality does not only display an association between future profitability in an in-sample framework but also in out-of-sample tests. Therefore, the second hypothesis, in the null form, is:

$\mathrm{H} 2$ : The usefulness of accounting information for predicting future profitability does not improve after the adjustment for earnings quality.

The last part of the paper considers the question of whether market participants efficiently use earnings quality information. As a first group of market participants, I analyze whether financial analysts efficiently incorporate earnings quality information into their decision-making process, or alternatively, in the null form:

H3: Financial analysts do not incorporate information about earnings quality in their decision making process.

The second question addressed here is whether information on earnings quality is associated with market returns. With the employment of a long-window return test (12-month annual return test), I survey the value relevance ('Interpretation 4' of value relevance as suggested by Francis and Shipper [1999]) that investors devote to earnings quality in their forecasts. Accordingly, the third hypothesis is in its null form:

H4: Profitability forecasts, adjusted for earnings quality, do not deliver additional information about future market returns. 


\section{Research design and data}

3.1. Measuring earnings quality

Prior research emphasizes a wide range of different market-based and accounting-based attributes to characterize earnings quality (see. Francis et al. [2004] for a review). ${ }^{3}$ Since my analyses are confined to financial statement information, I exclusively focus on accountingbased proxies. Dechow et al. [2010] highlight that earnings quality is jointly determined by the relevance of underlying financial performance and by the ability of the accounting system to measure performance. In practice, however, it is hard to disentangle these two determinants into mutually exclusive proxies. The following section explains the specific selection of two earnings quality proxies out of this wide range of suggested proxies in the accounting literature and why I assign them to explain the influence either from fundamental performance or from the accounting system.

Figure 1 depicts the disaggregation of RNOA into its first and second-order components. Standard DuPont analysis captures on the first-order decomposition the influence and persistence of ATO and PM as they contribute to firms' profitability. In doing so, PM measures the change in firms' ability to control costs while generating revenues. ATO measures the change in asset utilization and efficiency in generating revenues. Regular slope coefficients of ATO and PM in a regression model on future RNOA cannot distinguish whether fundamental performance or the accounting system drives firms' performance. This lack of information could distort forecasts. For instance, a firm could compensate for diminishing returns from mean reversion in its markets (e.g. new competitors, lower demand) by releasing hidden reserves, built by applying conservative accounting principles, into earnings. Up to a certain degree, the release of those reserves through changes in the accounting system could

\footnotetext{
${ }^{3}$ For instance, Francis et al. [2004] consider seven properties that are desirable features of earnings: accrual quality, persistence, predictability, smoothness, value relevance, timeliness, and conservatism.
} 
reduce the diminishing returns. But once it has reached a certain threshold where all reserves are expended, PM is likely to decrease by the adverse market conditions.

To integrate earnings quality influences in DuPont analysis, I investigate the impact of earnings quality proxies as they emerge from fundamental performance, not only by the slope coefficients of ATO and PM but also by disaggregated second-order components. A decline (increase) in PM could either occur through increasing (decreasing) costs as indicated by net income (NOI) in the numerator or through diminishing (ascending) revenues (e.g. changes in sales rates and sales prices) in the denominator, or both. With regard to fundamental performance, the persistence ${ }^{4}$ of NOI may reflect how operating efficiency is influenced by shifts in the cost structure. A stable PM ratio might therefore indicate persistent earnings or, alternatively, an adaptable accounting system (adoption of more liberal or more conservative accounting principles) that compensates for the lack of fundamental performance. To control for the influence of accounting principles, one needs a proxy for conservatism ${ }^{5}$ that captures the quality of reported earnings as reported by PM. Accordingly, changes in ATO may result due to changes in sales or to the productive use of assets. The choice of using different accounting principles does not only affect firms' income statement by recognizing expenditures like R\&D or advertisements, but also firms' balance sheet which influences ATO (e.g. LIFO accounting is more conservative than FIFO accounting since it carries lower LIFO amounts). Therefore, the persistence of sales indicates the share of recurring revenues that contribute to firms' fundamental profitability, whereas a measure for conservatism on the balance sheet

\footnotetext{
${ }^{4}$ Dechow et al. [2010] find earnings persistence the most used proxy for earnings quality in equity valuation frameworks to describe the sustainability of firm performance. Since forecasting exhibits distinct similarities to valuation frameworks, I tie on this literature stream by using earnings persistence rather than the smoothness of earnings or the like.

${ }^{5}$ Earnings quality gets influenced by an array of different determinants from the accounting system. However, most of those determinants are opaque and couldn't be conceived by studying firms' financial statements. Penman and Zhang [2002] suggest for this purpose a parsimonious ratio estimating the degree to which firms apply conservative accounting principles. I adopt this methodology because all information are disclosed in financial statements without the need of any further external sources.
} 
indicates an estimation to what extent the accounting system influences firm's profitability ratios.

Last, I control how growth in both, ATO and PM, affects future profitability. Thereby, growth is not seen as a proxy for earnings quality but rather as a control variable that is found to interact with profitability components and earnings quality proxies (e.g. conservative accounting). I therefore interact growth with second-order DuPont components and add growth as separated control variable to the forecast model as suggested in the FSA literature (e.g. Fairfield and Yohn [2001]).

To identify the effect of these earnings quality proxies on future profitability, I interact each proxy as they appear from second-order decomposition with ATO and PM, respectively. This way, I modulate a conditional association between the influence of earnings quality on first-order components and future profitability. Figure 1 illustrates how interactions between first and second-order effects detangle the influence of fundamental performance and the impact of earnings quality for predicting one-year-ahead RNOA.

[Insert Figure 1 around here]

This paper follows Barton et al. [2010] by defining the persistence of the DuPont component $X$ of firm $i$ at time $t$ as the slope coefficient $\beta_{i, 1}$ in the first-order autoregressive model:

$$
X_{i, t}=\alpha_{i, 0}+\beta_{i, 1} X_{i, t-1}+\varepsilon_{i, t}
$$

I measure the persistence of two second-order DuPont components: First, the persistence of net operating income (NOI) indicates the stability of firms' profit margin by generating a steady stream of net income. Second, the persistence of revenues (REVT) explains the sustainability of asset turnover attributable to recurring revenues. For each observation, I run firm individual regressions over the past four years. Higher values of $\beta_{i, l}$ indicate more 
persistent performance. More sustainable performance is likely to be a more useful input into forecast models. Consequently, the quality of accounting information gets more valuable.

The proxy for the quality of the accounting system is the degree to which firms practice conservative accounting. Francis et al. [2004] characterize conservatism as a market-based proxy since it is intended to measure the differential ability of accounting earnings to reflect economic losses (negative stock returns) versus economic gains (positive stock returns). However, since further analyses are constrained by a closed accounting framework, I follow the Penman and Zhang [2002] measure that aggregates indicators of conservatism from both the balance sheet and the income statement into a scoring system. The so called C-Score thus represents an accounting-based proxy rather than a market-based proxy for conservatism. The C-Score measures the effect of conservative accounting on the balance sheet by summing up capitalized R\&D $\left(X R D_{i, t}\right)$, capitalized advertising expense $\left(X A D_{i, t}\right)$, and LIFO reserves $\left(\operatorname{LIFR}_{i, t}\right) .{ }^{6}$ These unrecorded reserves originated by operating items in the balance sheet are then scaled by $\mathrm{NOA}_{\mathrm{i}, \mathrm{t}}$ :

$$
C_{i, t}=\frac{L I F R_{i, t}+X A D_{i, t}+X R D_{i, t}}{N O A_{i, t}}
$$

Whereas the C-Score captures the impact of conservative accounting for the effectiveness of asset utilization (ATO), the Q-Score measures the impact of conservatism on OI in the income statement. Again, I follow Penman and Zhang [2002] by defining the Q-Score as the weighted sum of one-year change in firm's C-Score $\left(Q_{i, t}^{\text {firm }}\right)$ and firm's C-Score in relation to the total market $^{7}\left(\mathrm{Q}_{\mathrm{i}, \mathrm{t}}^{\text {market }}\right)$ :

$$
Q_{i, t}=\left(0.5 \times Q_{i, t}^{\text {firm }}\right)+\left(0.5 \times Q_{i, t}^{\text {market }}\right)
$$

\footnotetext{
${ }^{6}$ Following Balachandran and Mohanram [2011], I capitalize and amortize R\&D over five years and advertising expenses over two years, using sum-of-years-digits amortization. If observations on R\&D and advertising are missing, I set them to zero.

${ }^{7}$ Penman and Zhang [2002] use the industry mean. For the sake of statistical power, I use again the market average. In control tests, I also use the industry average. Results do not change.
} 
where

$$
\begin{gathered}
Q_{i, t}^{\text {firm }}=C_{i, t}-C_{i, t-1} \\
Q_{i, t}^{\text {market }}=C_{i, t}-\text { market median }\left(C_{i, t}\right)
\end{gathered}
$$

The last earnings quality proxy is growth. Growing investments in operating assets not only influence firms' fundamental performance (Fairfield et al. [2003]) but also the impact of conservative accounting (Rajan et al. [2007]). Therefore, the influence of growth on earnings quality is neither exclusively assigned to fundamental performance nor to the accounting system. I define growth as the yearly change in NOA since operating activities and operating assets mainly drive firm value (Ohlson [1995]).

\subsection{Forecasting approaches}

The main research design consists of three steps. The first step examines the in-sample relation of earnings quality proxies on DuPont analysis forecasts. Next, I evaluate the out-ofsample performance with the same evaluation metric as in step one. Finally, I investigate how market participants use earnings quality information for predicting future firm performance and stock market performance.

Following previous literature (e.g. Fama and French [2000], Fairfield and Yohn [2001]), in-sample estimations are conducted with yearly cross-sectional regressions. To demonstrate the influence of earnings quality on the explanatory power of future profitability, I contrast the earnings quality adjusted forecast model against an established forecast model that embraces findings from prior research for explaining $\triangle \mathrm{RNOA}_{\mathrm{t}+1}$ : 
BM-Model: $\quad \Delta R N O A_{t+1,(i)}=\alpha_{i}+\beta_{1} R N O A_{t,(i)}+\beta_{2} \Delta A T O_{t,(i)}+\beta_{3} \Delta P M_{t,(i)}+$

$$
+\beta_{4} \Delta I N T_{t,(i)}+\beta_{5} \Delta N O A_{t,(i)}+\varepsilon_{t+1,(i)}
$$

EQ-Model: $\quad \Delta R N O A_{t+1,(i)}=\alpha_{i}+\beta_{1} R N O A_{t,(i)}+\beta_{2} \Delta A T O_{t,(i)}+\beta_{3} \Delta P M_{t,(i)}+\beta_{4} \Delta I N T_{t,(i)}+$

$$
\begin{aligned}
& +\beta_{5} \Delta A T O_{t,(i)} * \gamma_{t,(i)}+\beta_{6} \Delta A T O_{t,(i)} * \kappa_{t,(i)}+\beta_{7} \Delta A T O_{t,(i)} * \pi_{t,(i)}+ \\
& +\beta_{8} \Delta P M_{t,(i)} * \gamma_{t,(i)}+\beta_{9} \Delta P M_{t,(i)} * \kappa_{t,(i)}+\beta_{10} \Delta P M_{t,(i)} * \pi_{t,(i)}+ \\
& +\beta_{11} \Delta N O A_{t,(i)}+\varepsilon_{t+1,(i)}
\end{aligned}
$$

where,

$\gamma_{t,(i)}: \quad$ Growth in net operating assets $(\Delta \mathrm{NOA})$

$\kappa_{t,(i)}: \quad$ Conservative accounting. The EQ-Model applies the yearly change of the C-

Score for $\triangle A T O$, and the Q-Score for $\triangle P M$ (the Q-Score already contains the yearly change of the C-Score)

$\pi_{t,(i)}: \quad$ Persistence of profitability components. The EQ-Model utilizes the persistence of sales for $\triangle A T O$, and persistence of earnings (NOI) for $\triangle P M$

$t,(i): \quad$ year $t$, firm $i$

The benchmark model (BM) disaggregates the change in current RNOA into changes in ATO and PM. Following findings from Fairfield and Yohn [2001], the model additionally includes the actual level of RNOA and a variable labeled $\triangle \mathrm{INT}$ that captures the interaction between $\triangle \mathrm{PM}$ and $\triangle \mathrm{ATO}$. The variable $\triangle \mathrm{INT}$ originates from the mathematical transformation of $\triangle$ RNOA along the DuPont disaggregation as shown in Fairfield and Yohn [2001] and is added to our forecast model for the sake of completeness. The BM-Model accordingly serves as a benchmark model for previous findings in the literature on forecasting future profitability.

The earnings quality enhanced model (EQ-Model) additionally incorporates earnings quality information. I interact both DuPont components $\triangle \mathrm{ATO}$ and $\triangle \mathrm{PM}$ with proxies that capture the effects from fundamental performance and the accounting system on earnings quality. Previous research also argues that capital expenditures have a negative association with 
future earnings (e.g. Ou [1990], Abarbanell and Bushee [1997]). To validate that my findings are not solely a result of growth, I add the change in net operating assets to both models.

Lev et al. [2010] motivate research not merely to investigate the explanatory power of forecasts in-sample but rather as a challenge that real investors have to face. This is to test the usefulness of a model not only backward but also forward in an out-of-sample prediction. I use the same data and models for the out-of-sample prediction as the in-sample estimation. To provide higher inter-temporal stability for in-sample coefficients, I use rolling 5-year regressions. The out-of-sample forecast of $\triangle \mathrm{RNOA}$ in 2000 , for instance, refers to in-sample coefficients that are estimated from 1994 to 1998 to explain $\triangle$ RNOA in 1999 . These in-sample coefficients are applied to data from 1999 to forecast $\triangle$ RNOA in 2000 out-of-sample.

\subsection{Sample}

The sample of this study starts with 72,581 U.S. firm-year observations $(10,479$ unique firms) in the COMPUSTAT dataset in the period from 1990 through 2012, for which sufficient information is available to calculate all independent and dependent variables. Financial firms and institutes with SIC codes from 6000 to 6999 are excluded. Appendix 1 summarizes the variable definitions used for the in-sample coefficients and analyses. For distinguishing between operating and financial activities, I refer to the approach suggested by Callen and Segal [2005]. To further mitigate concerns that extreme observations drive the results for the in-sample estimation and out-of-sample prediction, I comprehensively eliminate firms based on several criteria. First, I exclude firms with negative values for several DuPont coefficients and components that are needed to calculate earnings quality proxies in year $t(11,473$ observations). To reduce the effect of mergers and acquisitions, I delete firms with growth in NOA that is greater than 100 percent in $\mathrm{t}(1,244$ observations). Outliers with changes in DuPont 
components that exceed 50 percent are also excluded $(13,640)$. Firms with missing or extreme values for earnings quality proxies (conservatism and persistence) are removed $(14,306)$. Finally, all in-sample coefficients are winsorized at the 1 percent level from both sides. These criteria yield in a final sample of 17,808 firm-years and 3,776 unique firms for in-sample estimations. All sample adjustments are consistent with previous studies on DuPont analysis (Fairfield and Yohn [2001]; Soliman [2008]) in order to facilitate comparison among studies. For out-of-sample forecasts, I do not apply any screenings for the predicted variable $\left(\Delta \mathrm{RNOA}_{\mathrm{t}+1}\right)$ to avoid a look-ahead-bias. Finally, all observations before 1996 that are used for the in-sample estimation are excluded. This results in 12,478 firm-years and 3,015 unique firms with out-of-sample forecasts from 1996 through 2012. Table 1 resumes the data selection process.

\subsection{Descriptive statistics and correlations}

Table 2 presents the descriptive statistics and correlations for the variables used in this study. Panel A reports the descriptive statistics for all firm-years in the in-sample estimation. Most of the values are consistent with prior literature. The mean and median of $\Delta \mathrm{RNOA}_{\mathrm{t}+1}$ is more negative than in older studies (e.g. Fairfield and Yohn [2001]). In addition to the mean reverting tendency of $\Delta \mathrm{RNOA}_{t+1}$, further analyses (not reported) reveal that yearly changes in RNOA got more negatively pronounced values during the financial crises between 2007 and $2009\left(-1.79 \%\right.$ on average). However, the change in profit margin $\left(\Delta \mathrm{PM}_{\mathrm{t}}\right)$ exhibits for both the mean $(1.47 \%)$ and median $(0.67 \%)$ positive values. Accounting conservatism, measured as CScore (0.086 on average) and Q-Score (0.059), are likewise comparable to recent research (Balachandran and Mohanram [2011]). Revenues exhibit the most stable persistence (0.60 on average), whereas earnings (0.16) possess far less sustainability. 
Panel B presents Pearson and Spearman rank correlations among the variables. Most of the correlation coefficients are statistically different from zero. Most earnings quality proxies show a statistically significant correlation with actual first-order DuPont components $\left(\triangle \mathrm{ATO}_{\mathrm{t}}\right.$ and $\left.\Delta \mathrm{PM}_{\mathrm{t}}\right)$ and with one-year-ahead changes in RNOA. Growth $\left(\Delta \mathrm{NOA}_{\mathrm{t}}\right)$ and $\Delta \mathrm{RNOA}_{t+1}$ correlate negatively. Persistence in firms' net income and revenues exhibit a significantly negative correlation between $\triangle \mathrm{RNOA}_{\mathrm{t}+1}$ what indicates mean-reversion for firms with highly sustainable income and sales in the past. $^{8}$

[Insert Table 2 around here]

\section{Empirical results}

4.1. Relative usefulness of earnings quality information in accounting forecast models for explaining and predicting future profitability

Does the quality of reported earnings affect the predictability of future profitability?

Figure 2 presents results from the BM-Model that estimates one-year-ahead changes in profitability by disaggregating profitability into changes in asset turnover and changes in profit margin as suggested in FSA textbooks (e.g. Lundholm and Sloan [2012]; Penman [2012]). The methodology is conducted as in Fairfield and Yohn [2001]. Detailed statistics concerning the in-sample estimation and the out-of-sample forecast are reported in the following sections. To motivate my research question that earnings quality factors could impact profitability predictions, I sort absolute forecast errors by proxies for earnings quality: accounting conservatism, growth, and persistence. As can be observed from all three plots, the accuracy of predicting future changes in profitability $\left(\Delta \mathrm{RNOA}_{\mathrm{t}+1}\right)$ almost linearly decreases with

\footnotetext{
${ }^{8}$ To avoid the influence of highly correlated coefficients in subsequent analyses, I additionally test if values for persistence of NOI and REVT (second-order persistence) and values for persistence of ATO and PM display multicollinearity. Tests reject this concern.
} 
absolute increasing values of each individual proxy for earnings quality. Increased growth in assets and increased divestitures in firms' assets raise the likelihood of higher forecast errors resulting from the ratio-based forecast model. The same applies to conservative accounting. Financial statements that are subject to more conservative accounting appear to bias not only the forecast accuracy of analysts (Mensah et al. [2004]) but also ratio-based prediction models. Last, Figure 2 demonstrates the dispersion of forecast errors as a function of earnings persistence. Between values of the persistence measure from $-0.5-0$ as well as $0-0.5$, one observes a threshold where forecast errors gradually increase with lower/higher earnings persistence. However, as the coefficient amplifies, the error rate noticeably leaps. This observation contradicts the intuition of earnings persistence because a more persistent earning stream should indicate a more useful summary measure for future profitability (Dechow et al. [2010]).

The results from prior FSA literature, earnings quality literature, and Figure 2 together suggest that earnings quality may influence profitability forecasts.

[Insert Figure 2 around here]

\subsubsection{Results from in-sample regressions}

The first empirical analysis considers the research question whether information about earnings quality of firms' performance and accounting system increases the explanatory power of accounting forecasts for predicting one-year-ahead changes in profitability. The prediction of future changes in profitability $\left(\Delta \mathrm{RNOA}_{t+1}\right)$ from in-sample regressions is shown in Table 3. Pooled regressions are exposed to cross-sectional correlation in the residuals (Bernard [1987]). I therefore estimate all coefficients from the rolling regression for each year and, accordingly, report mean coefficient estimates and the associated t-statistics as suggested by Fama and MacBeth [1973]. Following Bernard [1995], I also adjust coefficient estimates for cross- 
sectional correlation according to the Newey and West [1987] approach. The goodness of fit of each model is measured as the mean value of all average annual adjusted $\mathrm{R}^{2} \mathrm{~s}$. Barth et al. [2001] attribute $\mathrm{R}^{2}$ usefulness for comparing and evaluating prediction models.

[Insert Table 3 around here]

The BM-Model gives results from standard DuPont analysis without considering earnings quality information. This benchmark model mainly delivers consistent results with prior work. The actual level of RNOA is negative and highly significant which is indicative of mean reversion. The change in ATO is positive and also significant at the $1 \%$ level. However, $\triangle \mathrm{PM}$ is negative and significant in contrast to previous findings (Fairfield and Yohn [2001]; Soliman [2008]). This issue will be discussed in additional analyses (section 5.) in more detail.

By interacting $\triangle \mathrm{ATO}$ and $\triangle \mathrm{PM}$ with earnings quality proxies, though, previous results distinctively change as reported in the EQ-Model. Whereas the level of current RNOA still delivers highly significant explanatory power without altering the sign of influence, the influence of the change in ATO and PM significantly increases (absolute increase t-value $\Delta$ ATO: 5.07; absolute increase t-value $\Delta \mathrm{PM}: 3.21)$. This suggests that $\Delta \mathrm{ATO}$ and $\Delta \mathrm{PM}$ provide information about the emergence of future changes in RNOA beyond standard DuPont disaggregation. The coefficient on $\triangle \mathrm{PM}$ appears to bear on confounding influences from the quality of reported numbers in the income statement and, hence, most notably interacts with the conservatism proxy (Q-Score positive and significant at the 5\% level). Untabulated analyses reveal that an interaction term between $\triangle \mathrm{PM}$, growth and conservatism is highly significant for explaining year-ahead changes in RNOA. This is consistent with findings in Rajan et al. [2007] who claim that conservatism and growth are substitutes in their joint impact on changes in RNOA. Under the influence of conservative accounting, an increase in growth not only has a negative impact on future changes in RNOA, but also magnifies the use of conservative accounting. 
The second component of DuPont disaggregation, $\triangle \mathrm{ATO}$, does not exhibit a statistically significant interaction with the three earnings quality proxies in the in-sample estimation. The growth variable is negative and highly significant in the BM-Model as well as in the EQ-Model. The adjusted-R ${ }^{2}$ rises from $3.61 \%$ to $3.83 \%$ between both models. A Vuong [1989] test compares the explanatory power of the BM-Model and EQ-Model. The earnings quality enhanced forecast model explains future changes in RNOA significantly better than the BM-Model.

Taken together, although after controlling for growth, the consideration of earnings quality increases the explanatory power of the forecast model, even most interactions between earnings quality proxies and DuPont components are not statistically significant. However, traditional DuPont analysis seems not be able to fully capture this effect. To show that this phenomenon not only appears in in-sample estimations, I discuss in the next session whether the consideration of earnings quality leads to improvements in out-of-sample forecasts.

\subsubsection{Evaluation of out-of-sample prediction}

This section documents the usefulness of earnings quality information for predicting one-year-ahead changes in RNOA out-of-sample. I apply the obtained in-sample estimations from yearly cross-sectional regressions to test the accuracy of each model individually and against each other. Table 4 presents summary results on the descriptive statistics of out-ofsample tests. Panel A reports the mean, median and standard deviation of each forecast and of the signed/absolute forecast error. The signed (absolute) forecast error is defined as the (absolute) difference between actual values and the forecast. Panel B documents direct comparisons of the forecasting accuracy between the BM-Model and EQ-Model for each firmyear. I contrast both models from Table 3 in a matched-pair comparison for their absolute 
forecast errors by evaluating each firm-year from 1996 through 2012. I annually calculate mean and median improvements in prediction accuracy and finally report the grand mean and median values. If the reported value displays a positive sign, the second-mentioned prediction model performs superior in contrast to the first-mentioned model.

[Insert Table 4 about here]

The average absolute forecast error is 0.0714 (median 0.0464) for the BM-Model and 0.0708 (median 0.0458) for the EQ-Model. Accordingly, the earnings quality enhanced model distinctively improves the forecast accuracy in both the mean and median. Panel B shows how both prediction models perform in a direct contrast to each other. The improvement of the EQModel is significant in the mean and median. In addition, I document the number of yearly improvements or worsening. The EQ-Model significantly ${ }^{9}$ outperforms the traditional BMModel with improvements (worsening) in $6(0)$ years.

To deepen the knowledge of the forecast errors, I investigate which coefficients, and to what extent, mainly drive the forecast errors in my prediction models. Table 5 presents results on the association between absolute forecast errors (BM model and EQ model), disaggregated DuPont components, and earnings quality proxies. Since my research question investigates how earnings quality affects DuPont forecasts, I analyze how the explanatory of DuPont components changes after adding earnings quality information to the prediction models. For this purpose, I use multivariate regression models where absolute forecast errors from both disaggregated DuPont models serve as different dependent variables. To obtain comparability among models, I refer each dependent variable to the same regressors. Hereby, independent variables encompass traditional DuPont components, earnings quality proxies used for in- and out-of-sample predictions, as well as control variables. Multivariate tests (summaries based on

\footnotetext{
9 Tests are based on the mean t-statistic values (according to Fama and MacBeth [1973]) of yearly improvements/worsening and are only reported when a two-tailed t-test is at least significant on the $10 \%$ level or less.
} 
the eigenvalues of the regressor matrix from MANOVA), reported at the bottom of Table 5, test the null that all parameters except the intercept are the same for each dependent variable of two models, respectively.

\section{[Insert Table 5 around here]}

The left side of Table 5 documents results for the benchmark model. Changes in PM $(\mathrm{t}=4.32)$ exhibit significant influence on the absolute forecast error. Changes in ATO contribute less to the absolute forecast error $(\mathrm{t}=-1.38)$. Persistence in net income and revenues are significant at the $1 \%$ level. In direct comparison, the EQ-Model, that interacts DuPont components with earnings quality proxies, reports considerably weaker impact of $\triangle \mathrm{ATO}(\mathrm{t}=$ $-0.89)$ and $\Delta \mathrm{PM}(\mathrm{t}=2.08)$ on explaining prediction errors. These findings suggest that the sole use of disaggregated DuPont components still contributes a significant share to the emergence of forecast errors. It also indicates that the mutual treatment of disaggregated DuPont comments with the control for biases due to changes in earnings quality captures their effect on future profitability more accurately in out-of-sample forecasts. The differences in the explanatory power of the two independent variables for explaining the absolute forecast errors of both models are significant as revealed by the reported multivariate tests. Table 5 also documents that all models fail to predict a future loss as indicated by firms' reported net income in period $\mathrm{t}+1$.

Taken together, the results in Table 4 and 5 are consistent with the predictions of theory: information on earnings quality provides explanatory power for future profitability in insample estimations as well as in out-of-sample forecasts. 


\subsection{Examination of analyst and investor expectation}

My preliminary findings suggest that the accuracy of profitability forecasts based on DuPont disaggregation is positively associated with the integration of earnings quality information. In an efficient capital market, I expect the impact of earnings quality on profitability forecasts to be reflected in investors' expectations. In the following section, I examine hypotheses $\mathrm{H} 3$ and $\mathrm{H} 4$ whether both proxies for market participants, forecasts of financial analysts and market prices, are consistent with the impact of earnings quality on the predictability of future firm performance as stated in my preceding findings.

\subsubsection{Analysts' use of earnings quality information for predicting profitability}

Previous studies have examined analysts' forecasts as a function of earnings quality in order to shed light of whether this group of market participants incorporates earnings quality attributes in their forecasts (e.g. Elliott and Philbrick [1990], Bhattacharya et al. [2003]). Under the assumption that analysts are unbiased and sufficiently qualified, analysts' forecasts have the advantage relative to stock prices in terms of being an appropriate earnings quality proxy that they relate only to earnings, whereas market prices also reflect other information than earnings (Dechow et al. [2010]). This being the case, I first investigate investors' expectations by examining the association of one-year-ahead earnings predictions from analysts with the out-of-sample forecasts from both types of DuPont disaggregation models that either include or exclude earnings quality information. If analysts effectively incorporate earnings quality information in their prediction models, then their forecasts should be more closely related to the earnings quality enhanced DuPont disaggregation than to the traditional disaggregation.

I use analysts' most recently reported one-year-ahead earnings prediction for period t after the fiscal year-end for year t-1 from the I/B/E/S database from 1996 through 2012. I test analysts' perception towards information of traditional DuPont analysis (BM-Model) as well 
as towards the earnings quality enhanced models (EQ-Model). These associations are measured via the following regression analysis:

$$
\text { Prediciton }^{\text {Analysts }}\left(\triangle R N O A_{t+1,(i)}\right)=\alpha_{0}+\beta_{1} \text { Prediciton }^{\text {Model }}\left(\Delta R N O A_{t+1,(i)}\right)+\varepsilon_{t+1,(i)}
$$

where the dependent variable represents the median consensus forecast of one-year-ahead $\triangle$ RNOA from analysts for firm $i$ and where the independent variable captures the influence of the two different DuPont disaggregation models, respectively.

Table 6 presents the estimation results for analysts' use of earnings quality information. The findings suggest that the EQ-Model is closer associated to analysts' forecasts than the traditional DuPont disaggregation (BM-Model). With regard to the adjusted-R ${ }^{2}$, the EQ-Model explains $13.61 \%$ of the variation in analysts' profitability forecasts whereas the BM-Model only reports an explained variance of $11.96 \%$. Tests of differences in the explanatory power across the models (Vuong [1989] test) confirm that the EQ-Model is closer related to analysts' forecasts than the traditional BM-Model. Analysts therefore seem to use earnings quality information for their forecasts as stated in $\mathrm{H} 3$.

\section{[Insert Table 6 around here]}

\subsubsection{Investors use of earnings quality information for predicting profitability}

Since the previous section found that analysts seem to be aware of earnings quality information for predicting future changes in profitability, investors also may find this set of information valuable. For investigating the awareness of the stock market, I define two mechanical trading rules that may exploit investors' inefficient use of earnings quality information. I follow Berger and Hann [2003] and Fairfield et al. [2009] which suggest an approach to examine the accuracy of two competing models by examining the abnormal returns to three groups of portfolios (long, short, and hedge portfolio formation strategies). If market participants efficiently include earnings quality information in their decision making process, 
then buying (short-selling) stocks of firms where the earnings quality enhanced models predict higher (lower) changes in one-year-ahead changes in RNOA than the traditional DuPont model should generate abnormal returns. Stock data are obtained from the Center of Research in Security Prices (CRSP). Abnormal returns are calculated for a 12-month buy-and-hold period, beginning from the fourth month of year $t$ until the third month after fiscal year-end $t+1$. Market returns for the corresponding month are calculated on the basis of value-weighted returns of the total population of the data sample.

The results are presented in Table 7. Returns from the long side are on average positive over the entire sample period and also predominantly positive on a fiscal year basis. However, stocks from the short-selling portfolios mostly generate negative returns. ${ }^{10}$ After summing up the long and short portfolios, hedge returns are slightly negative, but not statistically different from zero. I can therefore not reject the hypothesis that investors use earnings information efficiently in predicting future changes in profitability with DuPont analysis. This test undergoes a quite simple trading heuristic, though, and leaves much room for improvement.

\section{[Insert Table 7 around here]}

\section{Additional analyses and robustness tests}

I subject my results to a battery of additional analyses as well as robustness and specification tests in untabulated analyses. Prior research raises the possibility that systematic inter-industry differences affect the accuracy of forecast models. To investigate the robustness of my results to this issue, I run in-sample and out-of-sample forecasts for firm groups within two-digit as well as four-digit GICS industry sectors obtained from COMPUSTAT. The EQModel outperforms the BM-Model in both industry specifications. Consistent with Fairfield et

\footnotetext{
${ }^{10}$ It may apply that the data selection process excluded several bad performing firms so that the underlying sample underlies a "winner bias". As a result, short-selling might not be an appropriate strategy having a right skewed return distribution.
} 
al. [2009], the results from the economy-wide forecasts lead to better results in predicting future profitability than the industry-specific models.

When conducting the in-sample estimation with rolling regressions, I observe that the actual change in PM exhibits significant explanatory power for one-year-ahead changes in RNOA. In contrast, previous research reports that $\triangle \mathrm{PM}$ is not incremental useful for predicting $\Delta \mathrm{RNOA}_{\mathrm{t}+1}$ by using yearly cross-sectional regressions. To evaluate that this difference is due to a different econometrical forecast approach rather than driven by different sample firms or changes over time, I calculate the in-sample coefficients for the BM-Model as well as the EQModel with yearly cross-sectional regressions. Inconsistent with prior findings, $\triangle \mathrm{PM}$ is negative and still significant. An inspection of yearly estimated coefficients reveals that the explanatory of $\Delta \mathrm{PM}$ increasingly raises over the past decade. My previous results concerning the influence of firms' earnings quality for predicting profitability stay stable. Additionally, I test whether the rolling regression or the cross-sectional based forecast perform better. In the grand mean and median, rolling regression-based forecasts beat cross-sectional forecasts. However, the rolling regression is not superior on an annual level since it doesn't improve the forecast on a statistically significant level in a single year.

Last, I expand the proxies for conservative accounting as suggested by Penman and Zhang [2014]. I find that altering the definition of the C-Score and Q-Score does not affect my results.

\section{Conclusion}

This paper tests how the reporting quality of earnings affects the accuracy of ratio-based forecast models. I combine distinct findings from both literature streams, earnings quality research and financial statement analysis literature, to test their mutual impact on profitability forecast models. Adding earnings quality information to ratio-based forecasts provides 
incremental information over standard DuPont disaggregation, including the level of current RNOA and growth in net operating assets, as suggested in prior studies. I provide evidence that the explanatory power of in-sample estimations increases and that the forecast accuracy of outof-sample forecasts improves.

My results provide researchers and practitioners with a parsimonious method for adjusting FSA forecasts to the bias through contemporaneous changes in the quality of reported earnings. However, by analyzing the association between earnings quality enhanced forecast models and analysts as well as stock market investors, I show that both market participants impound earnings quality information in their decisions. This result raises the question of how and to what extent market participants use earnings quality information. Further, future research could test whether markets therefore exclusively draw on financial statement information or whether other public or private sources provide information about the influence of earnings quality on firms' future performance. 
Figure 1

Figure 1: Unconditional and conditional relation between first and second order components of DuPont analysis with one-year-ahead RNOA

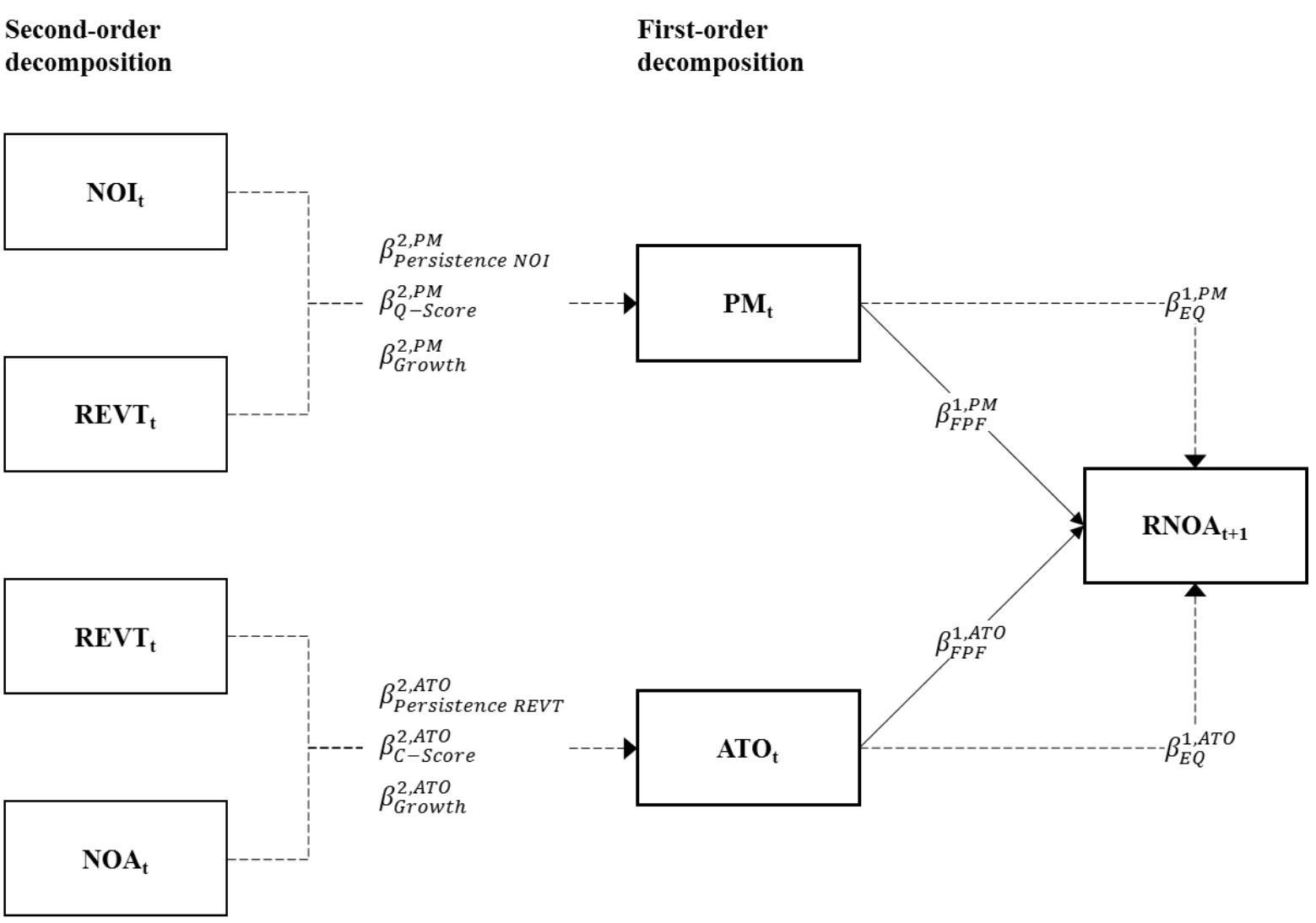

Notes:

Figure 1 shows the first and second-order DuPont decomposition. See Appendix 1 for variable definitions. The direct link between PM/ATO $\left(\beta_{F P F}^{1, A T O} / \beta_{F P F}^{1, P M}\right)$ and RNOA modulates the aggregated influence of firms' unconditional fundamental performance as it arises from the first-order DuPont decomposition. The conditional association between PM/ATO and RNOA is constructed via an indirect link that detangles earnings quality influences as they arise from the persistence of NOI and REVT and conservative accounting. The influence of growth is also added as control. By interacting ATO/PM with these earnings quality proxies, one indirectly creates a conditional link $\left(\beta_{E Q}^{1, A T O} / \beta_{E Q}^{1, P M}\right)$ between the second-order and the first-order decomposition for explaining one-year ahead RNOA. 
Figure 2

Figure 2: Association between accuracy of DuPont analysis based forecasts and different degrees of growth, conservatism, and persistence

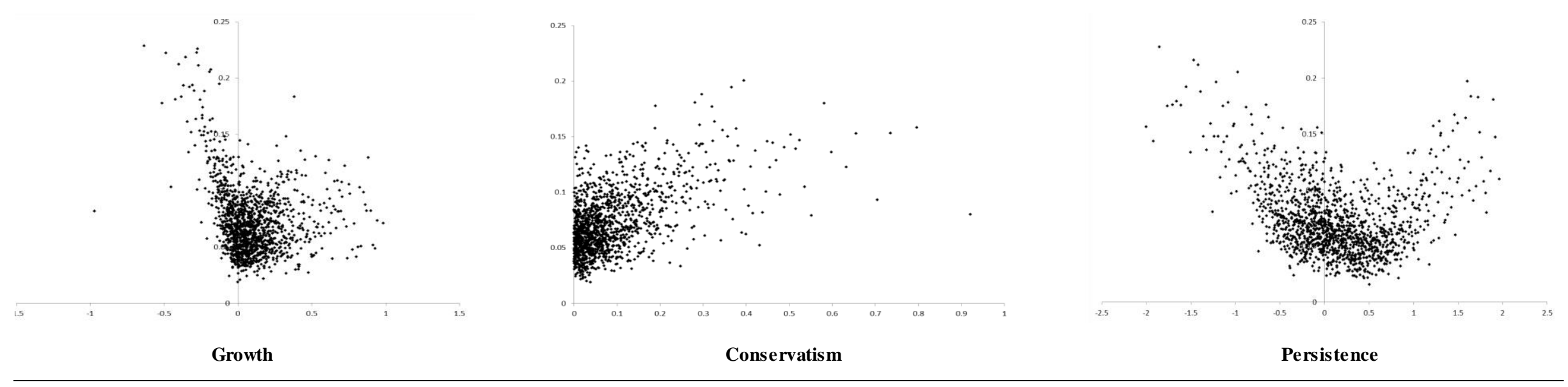

\section{Notes:}

Figure 2 shows the relation between the level of absolute forecast errors (y-axis) from out-of-sample forecasts using DuPont analysis (prediction of $\Delta$ RNOA $A_{t+1}$ ) under different levels of growth $\left(\triangle \mathrm{NOA}_{\mathrm{t}}\right)$, conservatism $\left(\mathrm{C}-\mathrm{Score}_{\mathrm{t}}\right)$ and persistence of profitability (persistence $\mathrm{RNOA}_{\mathrm{t}}$ ). See Appendix 1 and section 3.1 for variable definitions. The forecast approach is described in section 3.2 (BM-Model). Table 3 and 4 report in-sample and out-of-sample statistics of the forecast model and forecast errors in detail. Each dot represents the mean of 10 out-of-sample forecast errors (total=12,478 firm-years) from 1996 to 2012. 
Table 1

Table 1: Sample Selection

less firm-year observations characterized by:

Financial industry classification and possessing segments according to the Global

Industry Classification Standard

Negative observations for $N O A_{t}, A T O_{t}, P M_{t}, X A D_{t}, X R D_{t},{L I F R_{t}}$

Absolute percentage change in $\mathrm{NOA}_{t}, \mathrm{NOA}_{t+1}>100 \%$

Absolute percentage change in $R N O A_{\mathrm{t}}, \mathrm{RNOA}_{t+1}, A T O_{t}, A T O_{t+1}, \mathrm{PM}_{t}$,

$P M_{t+1}>50 \%$

Absolute value of $\mathrm{C}-$ Score $_{\mathrm{t}}=0$ or $>5$ and of persistence $>1$

All variables for the insample-estimation were winsorized at the $1 \%$ level from both sides

Observations used for the forecast model 


\section{Table 2}

Table 2: Descriptive statistics and correlations for variables used to estimate in-sample regression coefficients Panel A: Descriptive statistics

\begin{tabular}{|c|c|c|c|c|c|c|c|}
\hline Variables & Mean & Median & STD & Q1 & Q3 & Min & Max \\
\hline$\Delta \mathrm{RNOA}_{\mathrm{t}+1}$ & -0.01808 & -0.00502 & 0.09497 & -0.05546 & 0.03225 & -0.35746 & 0.21954 \\
\hline$\Delta \mathrm{RNOA}_{\mathrm{t}}$ & 0.01408 & 0.00635 & 0.09347 & -0.03195 & 0.04885 & -0.23758 & 0.34996 \\
\hline RNOA & 0.18289 & 0.15449 & 0.13010 & 0.09228 & 0.23943 & 0.00722 & 0.68794 \\
\hline $\mathrm{ATO}_{\mathrm{t}}$ & 2.02500 & 1.84383 & 1.03278 & 1.31602 & 2.49325 & 0.39687 & 5.89607 \\
\hline $\mathrm{PM}_{\mathrm{t}}$ & 0.10260 & 0.08664 & 0.07212 & 0.05055 & 0.13550 & 0.00405 & 0.36370 \\
\hline$\Delta \mathrm{ATO}_{\mathrm{t}}$ & -0.00333 & -0.00044 & 0.02201 & -0.01212 & 0.00757 & -0.08461 & 0.05757 \\
\hline$\Delta \mathrm{PM}_{\mathrm{t}}$ & 0.01469 & 0.00668 & 0.08673 & -0.02524 & 0.04345 & -0.22041 & 0.33687 \\
\hline$\Delta \mathrm{INT}_{\mathrm{t}}$ & 0.00009 & 0.00001 & 0.00225 & -0.00019 & 0.00034 & -0.01100 & 0.01018 \\
\hline$\Delta \mathrm{NOA}_{\mathrm{t}}$ & 0.08899 & 0.05216 & 0.18805 & -0.02606 & 0.15960 & -0.25803 & 0.88590 \\
\hline C-Score ${ }_{t}$ & 0.08559 & 0.05277 & 0.09534 & 0.02010 & 0.11666 & 0.00000 & 0.50557 \\
\hline Q-Score t $_{\mathrm{t}}$ & 0.05904 & 0.02624 & 0.09512 & -0.00614 & 0.08958 & -0.02872 & 0.47890 \\
\hline Persistence Revenues $_{t}$ & 0.60366 & 0.67580 & 0.58923 & 0.18603 & 1.03253 & -0.87899 & 1.82965 \\
\hline Persistence Earnings $_{t}$ & 0.16267 & 0.09375 & 0.58748 & -0.24365 & 0.56418 & -1.27166 & 1.60365 \\
\hline
\end{tabular}

Panel B: Spearman / Pearson (above) correlations

\begin{tabular}{|c|c|c|c|c|c|c|c|c|c|c|c|}
\hline & $\Delta \mathrm{RNOA}_{\mathrm{t}+1}$ & $\Delta \mathrm{RNOA}_{\mathrm{t}}$ & $\mathrm{RNOA}_{\mathrm{t}}$ & $\Delta \mathrm{ATO}_{\mathrm{t}}$ & $\Delta \mathrm{PM}_{\mathrm{t}}$ & $\Delta \mathrm{INT}_{\mathrm{t}}$ & $\Delta \mathrm{NOA}_{\mathrm{t}}$ & C-Score $_{\mathrm{t}}$ & Q-Score $_{\mathrm{t}}$ & $\begin{array}{l}\text { Persistence } \\
\text { Revenues }_{\mathrm{t}}\end{array}$ & $\begin{array}{l}\text { Persistence } \\
\text { Earnings }_{\mathrm{t}}\end{array}$ \\
\hline$\Delta \mathrm{RNOA}_{\mathrm{t}+1}$ & 1.000 & -0.039 & -0.118 & 0.098 & -0.068 & -0.022 & -0.115 & -0.005 & -0.003 & -0.036 & -0.043 \\
\hline$\Delta \mathrm{RNOA}_{\mathrm{t}}$ & -0.004 & 1.000 & 0.076 & 0.263 & 0.970 & -0.323 & -0.105 & 0.084 & 0.085 & -0.087 & -0.101 \\
\hline $\mathrm{RNOA}_{\mathrm{t}}$ & -0.143 & 0.113 & 1.000 & 0.010 & 0.087 & 0.042 & 0.169 & 0.205 & 0.205 & 0.219 & 0.326 \\
\hline$\Delta \mathrm{ATO}_{\mathrm{t}}$ & 0.114 & 0.351 & 0.059 & 1.000 & 0.065 & -0.062 & -0.271 & 0.023 & 0.023 & 0.004 & -0.045 \\
\hline$\Delta \mathrm{PM}_{\mathrm{t}}$ & -0.043 & 0.943 & 0.137 & 0.108 & 1.000 & -0.336 & -0.031 & 0.075 & 0.076 & -0.078 & -0.079 \\
\hline$\Delta \mathrm{INT}_{\mathrm{t}}$ & -0.010 & -0.131 & 0.052 & 0.009 & -0.176 & 1.000 & 0.060 & 0.004 & 0.004 & 0.004 & -0.017 \\
\hline$\Delta \mathrm{NOA}_{\mathrm{t}}$ & -0.158 & -0.131 & 0.244 & -0.251 & -0.042 & 0.030 & 1.000 & -0.094 & -0.096 & 0.246 & 0.209 \\
\hline C-Score ${ }_{t}$ & 0.013 & 0.073 & 0.174 & 0.024 & 0.065 & 0.010 & -0.067 & 1.000 & 0.999 & -0.044 & -0.037 \\
\hline Q-Score $_{\mathrm{t}}$ & 0.016 & 0.075 & 0.172 & 0.026 & 0.067 & 0.012 & -0.073 & 0.996 & 1.000 & -0.047 & -0.038 \\
\hline Persistence Revenues $_{t}$ & -0.053 & -0.067 & 0.268 & 0.020 & -0.055 & -0.027 & 0.304 & -0.033 & -0.040 & 1.000 & 0.324 \\
\hline Persistence Earnings $_{\mathrm{t}}$ & -0.068 & -0.097 & 0.326 & -0.045 & -0.062 & -0.049 & 0.215 & -0.030 & -0.033 & 0.337 & 1.000 \\
\hline
\end{tabular}

\section{Notes:}

See Appendix 1 for variable definitions. Panel A provides summary statistics for the 17,808 firm-years (3,776 unique firms) for the sample period between 1990 and 2012. Panel B shows Spearman (Pearson) correlations below (above) the diagonal. All correlations in italic are not significant at and below the $10 \%$ level. 
Table 3

Table 3: In-sample coefficients estimates $(1990$ - 2012)

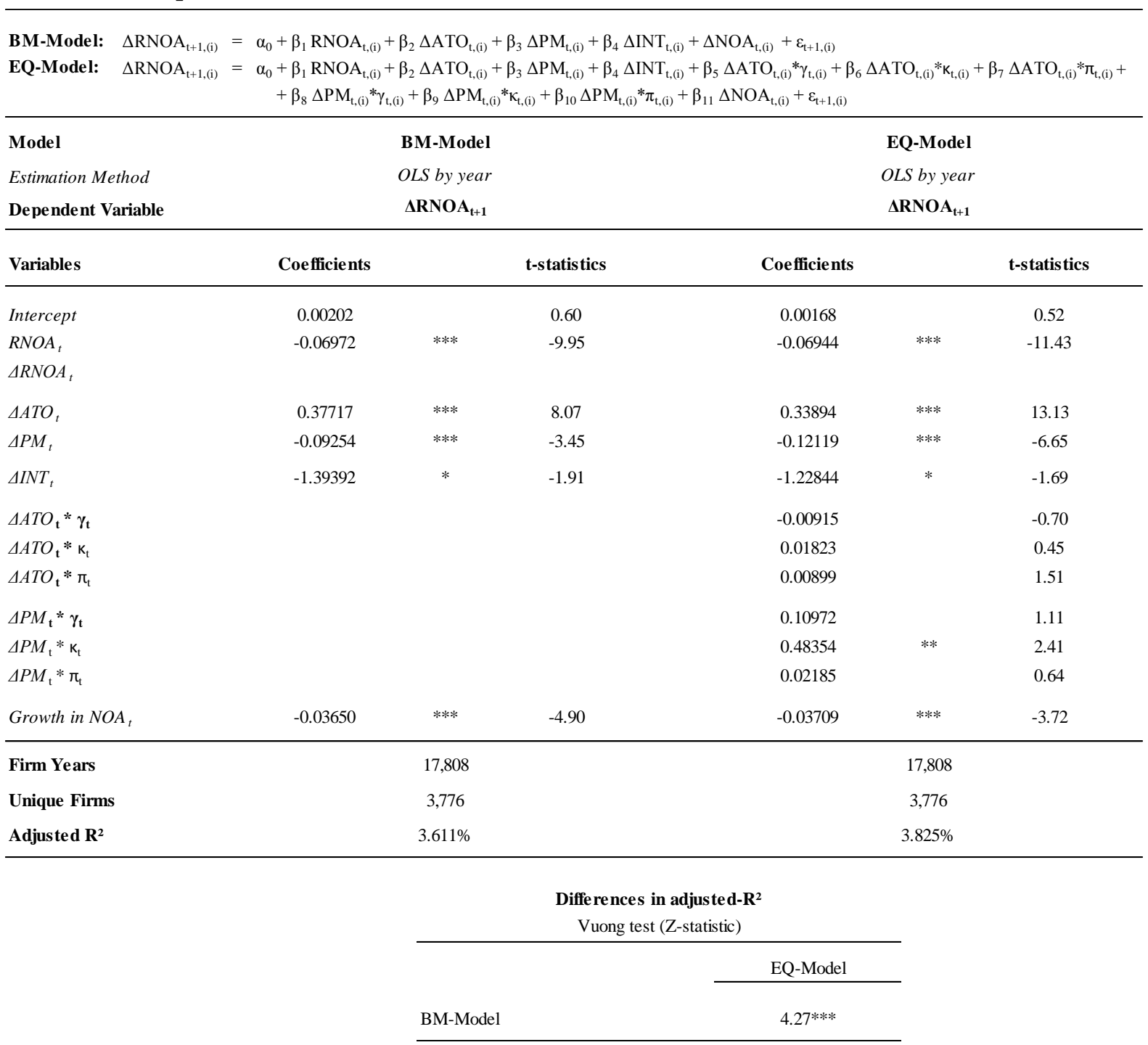

Notes:

This table presents the in-sample regressions of one-year ahead RNOA on (disaggregated) DuPont components and earnings quality proxies. For each model, yearly cross-sectional regressions are run for the whole subsample. T-statistics for coefficient estimates are computed using the Fama-MacBetch [1973] approach and are additionally adjusted for cross-sectional correlation as suggested by Bernard [1995]. The table also presents the z-statistics from Vuong [1989] tests of differences in explanatory power across the BM and EQ model. *,**, and *** denote statistical significance at $10 \%, 5 \%$, and $1 \%$ levels, respectively. 
Table 4

Table 4: Statistics on forecasts, forecast errors, and improvements from out-of-sample forecasts for $\Delta R N O A_{t+1}$ ( $\mathrm{n}=12,478$ firm-years / 3,015 firms / 1996 - 2012)

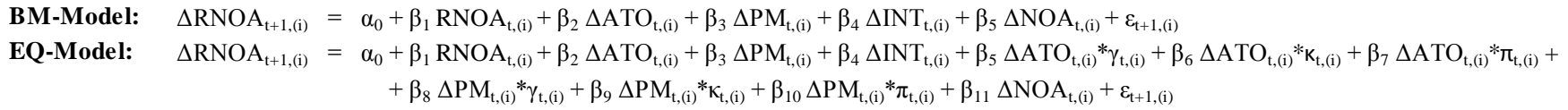

Panel A: Out-of-sample pooled descriptive statistics

\begin{tabular}{|c|c|c|c|c|c|c|c|c|c|}
\hline \multirow[b]{2}{*}{ Model } & \multicolumn{3}{|l|}{ Forecast } & \multicolumn{3}{|c|}{ Signed Forecast Error } & \multicolumn{3}{|c|}{ Absolute Forecast Error } \\
\hline & Mean & Median & STD & Mean & Median & STD & Mean & Median & STD \\
\hline $\mathrm{BM}$ & -0.0189 & -0.0159 & 0.0250 & 0.0000 & 0.0131 & 0.1091 & 0.0714 & 0.0464 & 0.0825 \\
\hline EQ & -0.0174 & -0.0154 & 0.0201 & -0.0014 & 0.0123 & 0.1087 & 0.0708 & 0.0458 & 0.0825 \\
\hline
\end{tabular}

Panel B: Out-of-sample tests of forecast improvements

\begin{tabular}{|c|c|c|c|c|c|c|c|}
\hline \multirow[b]{2}{*}{ Models Compared } & \multicolumn{3}{|c|}{ Mean improvement } & \multicolumn{3}{|c|}{ Median improvement } & \multirow[t]{2}{*}{ Number of yearly improvements } \\
\hline & Value & & $p$ value & Value & & $p$ value & \\
\hline BM vs EQ & 0.0006 & $* *$ & 0.01072 & 0.0003 & $* *$ & 0.02166 & $6 / 0$ \\
\hline
\end{tabular}

Notes:

Panel A reports the pooled mean, median, and standard deviation for the out-of-sample predictions. Signed forecast errors are the difference between the actual change of RNOA and the predicted change of RNOA. Absolute forecast errors are the absolute errors of the signed forecast errors.

Panel B presents anually grand mean and median improvements in the firm-specific forecast accuracy from out-of-sample prediciton. Forecast accuracy is computed through a matched-pair comparison of absolute forecast errors from two competing models for each firm-year. A positive value for Model A vs B indicates a relative improvement of Model B against Model A. Number of yearly statistically significant improvements are reported on the right side of Panel B. Improvements of models are based on tests of means (median) on Fama-MacBeth t-statistics (Wilcoxon signed rank tests). Number of yearly improvements are based on the yearly median improvements that are significantly positive/negative at the $10 \%$ level using two-tailed t-tests. *, **, and $* * *$ denote statistical significance at $10 \%, 5 \%$, and $1 \%$ levels, respectively. 
Table 5

Table 5: Association between disaggregated DuPont coefficients and absolute forecast errors (1996 - 2012)

\begin{tabular}{|c|c|c|c|c|c|c|}
\hline $\begin{array}{l}\text { BM-Model: } \\
\text { EQ-Model: }\end{array}$ & $\begin{array}{l}\text { AFE(BM-Model })_{t+1,(i)} \\
\text { AFE(EQ-Model })_{t+1,(\mathrm{i})}\end{array}$ & \multicolumn{5}{|c|}{$\begin{array}{l}=\alpha_{0}+\beta_{1} \mathrm{RNOA}_{\mathrm{t}, \mathrm{i})}+\beta_{2} \Delta \mathrm{ATO}_{\mathrm{t},(\mathrm{i})}+\beta_{3} \Delta \mathrm{PM}_{\mathrm{t}, \mathrm{i})}+\beta_{4} \Delta \mathrm{INT}_{\mathrm{t}, \mathrm{i})}+\sum \text { Controls }_{\mathrm{t},(\mathrm{i})}+\varepsilon_{\mathrm{t}+1,(\mathrm{i})} \\
=\alpha_{0}+\beta_{1} \mathrm{RNOA}_{\mathrm{t},(\mathrm{i})}+\beta_{2} \Delta \mathrm{ATO}_{\mathrm{t},(\mathrm{i})}+\beta_{3} \Delta \mathrm{PM}_{\mathrm{t},(\mathrm{i})}+\beta_{4} \Delta \mathrm{INT}_{\mathrm{t}, \mathrm{i})}+\sum \text { Controls }_{\mathrm{t},(\mathrm{i})}+\varepsilon_{\mathrm{t}+1,(\mathrm{i})}\end{array}$} \\
\hline Model & \multicolumn{3}{|c|}{ BM-Model } & \multicolumn{3}{|c|}{ EQ-Model } \\
\hline \multirow{2}{*}{$\begin{array}{l}\text { Estimation Method } \\
\text { Dependent Variable }\end{array}$} & \multicolumn{3}{|c|}{ Pooled OLS } & \multicolumn{3}{|c|}{ Pooled OLS } \\
\hline & \multicolumn{3}{|c|}{ Absolute forecast error } & \multicolumn{3}{|c|}{ Absolute forecast error } \\
\hline Variables & \multicolumn{2}{|l|}{ Coefficients } & t-statistics & Coefficients & & t-statistics \\
\hline Intercept & 0.11317 & $* * *$ & 4.17 & 0.11481 & $* * *$ & 4.24 \\
\hline$R_{N O A_{t}}$ & 0.09705 & $* * *$ & 17.26 & 0.09926 & $* * *$ & 17.68 \\
\hline$\triangle A T O_{t}$ & -0.04219 & & -1.38 & -0.02709 & & -0.89 \\
\hline$\Delta P M_{t}$ & 0.03472 & $* * *$ & 4.32 & 0.01668 & $* *$ & 2.08 \\
\hline$\Delta I N T_{t}$ & 0.04200 & & 0.14 & 0.11612 & & 0.39 \\
\hline Abn. persistenc revenues & -0.00324 & $* * *$ & -2.60 & -0.00327 & $* * *$ & -2.63 \\
\hline Abn. persistence NI & -0.00653 & $* * *$ & -5.23 & -0.00644 & $* * *$ & -5.18 \\
\hline C-Score & -0.78739 & & -0.84 & -0.90096 & & -0.96 \\
\hline$Q$-Score & 0.90849 & & 0.96 & 1.02030 & & 1.08 \\
\hline Growth in NOA & -0.00050 & & -0.13 & -0.00002 & & -0.01 \\
\hline Size & -0.00476 & $* * *$ & -14.01 & -0.00469 & $* * *$ & -13.81 \\
\hline Leverage & 0.00004 & & & 0.00005 & $* *$ & 1.74 \\
\hline Loss & 0.08694 & $* * *$ & 44.99 & 0.08935 & $* * *$ & 46.31 \\
\hline Industry Dummies & \multicolumn{3}{|c|}{ Yes } & \multicolumn{3}{|c|}{ Yes } \\
\hline Year Dummies & \multicolumn{3}{|c|}{ Yes } & \multicolumn{3}{|c|}{ Yes } \\
\hline Firm Years & \multicolumn{3}{|c|}{12,478} & \multicolumn{3}{|c|}{12,478} \\
\hline Unique Firms & & 3,015 & & & 3,015 & \\
\hline Adjusted $\mathbf{R}^{2}$ & & $22.83 \%$ & & & $23.06 \%$ & \\
\hline
\end{tabular}

p- vlaues from multivariate tests

of differences in explanatroy power for the dependent variable

\begin{tabular}{c}
\hline \\
\cline { 2 - 2 } BM-Model \\
$0.000 * * *$ \\
\hline
\end{tabular}

Notes:

This table presents the association between absolute forecast errors from out-of-sample forecasts (see Table 4) and DuPont coefficients. Each model uses forecast errors as dependent variable as they arise from their individual predictions. P-values from multivariate tests examine the hypothesis that all parameters except the intercept are the same for dependent variables of the two models. *,**, and *** denote statistical significance at $10 \%, 5 \%$, and $1 \%$ levels, respectively. 
Table 6

Table 6: Association between analysts' forecasts and RNOA predictions

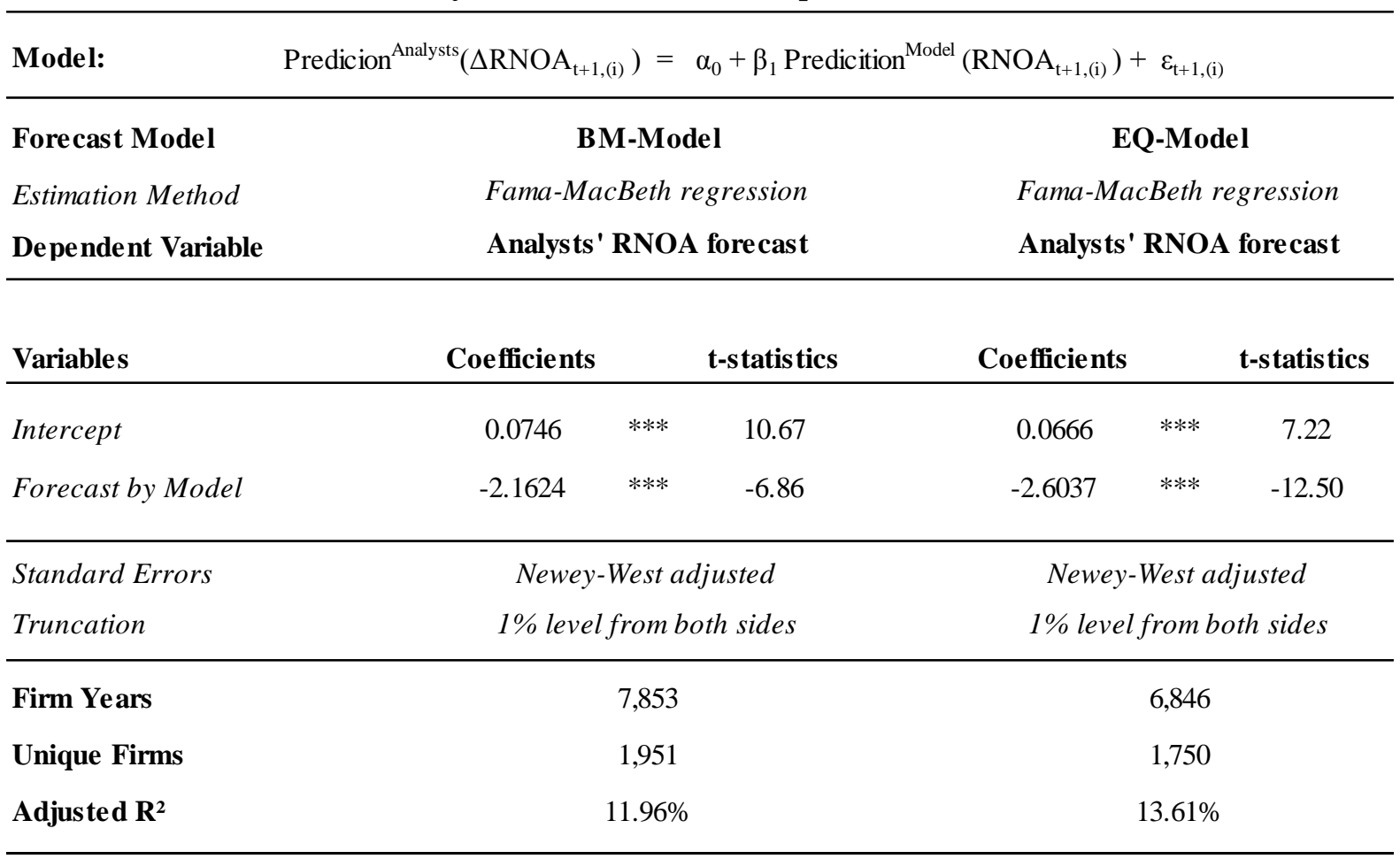

Differences in adjusted- $R^{2}$

Vuong test (Z-statistic)

\begin{tabular}{lcc}
\hline & BM-Model & EQ-Model \\
\cline { 2 - 3 } BM-Model & - & - \\
EQ-Model & $-3.81^{* * *}$ & - \\
\hline
\end{tabular}

Notes:

The sample consists of firm-year observations from 1996 - 2012. Regressions are estimated annually using the Fama-MacBeth [1973] approach of cross-sectional regressions for all firms (17 years). t-statistics are calculated as suggested by Bernard [1995]. The table also presents the z-statistics from Vuong [1989] tests of differences in explanatory power across the BM and EQ model. *,**, and *** denote statistical significance at $10 \%, 5 \%$, and $1 \%$ levels, respectively. 
Table 7

Table 7: Analysis of stock returns based on traditional DuPont analysis and earnings quality enhanced predictions - twelve-month abnormal returns of trading rule portfolios

\begin{tabular}{|c|c|c|c|}
\hline \multirow[b]{3}{*}{ Strategy } & \multicolumn{3}{|c|}{ Portfolio } \\
\hline & \multirow{2}{*}{$\begin{array}{l}\text { Long: } \\
\text { Short: } \\
\mathbf{N}\end{array}$} & \multicolumn{2}{|c|}{ 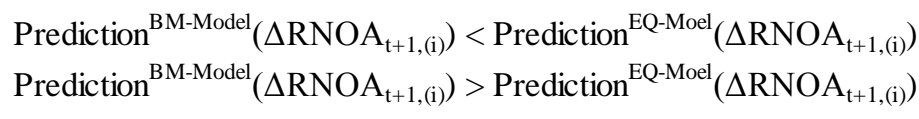 } \\
\hline & & 12-month BHAR & p-Value \\
\hline Hedge portfolio & 4,027 & & \\
\hline Years positive / negative & $9 / 8$ & & \\
\hline Mean return & & $-1.37 \%$ & 0.281 \\
\hline Median return & & $-0.31 \%$ & 0.768 \\
\hline Long portfolio & 2,033 & & \\
\hline Years positive / negative & $12 / 5$ & & \\
\hline Mean return & & $6.07 \%$ & 0.220 \\
\hline Median return & & $4.91 \%$ & 0.311 \\
\hline Short portfolio & 1,994 & & \\
\hline Years positive / negative & $5 / 12$ & & \\
\hline Mean return & & $-7.44 \%$ & 0.145 \\
\hline Median return & & $-5.21 \%$ & 0.288 \\
\hline
\end{tabular}

Notes:

This table presents the distribution of 12-month abnormal returns for a trading portfolio based on two prediction models using DuPont disaggregation (BM and EQ). The return cumulation period begins in the fourth month of each fiscal year and extends into the third month after the end of each fiscal year.The sample consists of firm-year observations from 1996-2012.

The 12-month abnormal buy-and-hold abnormal returns (book-to-market matched control firms) is computed as:

$$
\prod_{m=1}^{m=12}\left(1+R_{i, m}\right)-\prod_{m=1}^{m=12}\left(1+V W R_{m}\right)
$$

where $R_{i, m}$ is the monthly return of firm $i$, and $V W R_{m}$ is the value-weighted return for the corresponding month. See Berger and Hann [2013] for further details. 


\section{References}

Abarbanell, J.S. and Bushee, B.J., 1997. Fundamental analysis, future earnings, and stock prices. Journal of Accounting Research, 35 (1), 1-24.

Amir, E., Kama, I., and Livnat, J., 2011. Conditional versus unconditional persistence of RNOA components: implications for valuation. Review of Accounting Studies, 16 (2), 302-327.

Baik, B., Chae, J., Choi, S., and Farber, D.B., 2013. Changes in operational efficiency and firm performance: a frontier analysis approach. Contemporary Accounting Research, 30 (3), 996-1026.

Balachandran, S. and Mohanram, P., 2011. Is the decline in the value relevance of accounting driven by increased conservatism? Review of Accounting Studies, 16 (2), 272-301.

Ball, R. and Shivakumar, L., 2005. Earnings quality in UK private firms: comparative loss recognition timeliness. Journal of Accounting and Economics, 39 (1), 83-128.

Barth, M.E., Beaver, W.H., Hand, J.R., and Landsman, W.R., 2005. Accruals, accounting-based valuation models, and the prediction of equity values. Journal of Accounting, Auditing \& Finance, 20 (4), 311-345.

Barth, M.E., Clinch, G., and Israeli, D., 2015. What Do Accruals Tell Us About Future Cash Flows? Working Paper, Stanford University Graduate School of Business Research.

Barth, M.E., Cram, D.P., and Nelson, K.K., 2001. Accruals and the prediction of future cash flows. The Accounting Review, 76 (1), 27-58.

Barth, M.E., Landsman, W.R., and Lang, M.H., 2008. International accounting standards and accounting quality. Journal of Accounting Research, 46 (3), 467-498.

Barton, J., Hansen, T.B., and Pownall, G., 2010. Which performance measures do investors around the world value the most-And why? The Accounting Review, 85 (3), 753-789.

Beaver, W.H., Correia, M., and McNichols, M.F., 2012. Do differences in financial reporting attributes impair the predictive ability of financial ratios for bankruptcy? Review of Accounting Studies, 17 (4), 969-1010.

Beaver, W.H. and Ryan, S.G., 2000. Biases and lags in book value and their effects on the ability of the bookto-market ratio to predict book return on equity. Journal of Accounting Research, 38 (1), 127-148.

Beaver, W.H. and Ryan, S.G., 2005. Conditional and unconditional conservatism: Concepts and modeling. Review of Accounting Studies, 10 (2-3), 269-309.

Berger, P.G. and Hann, R., 2003. The impact of SFAS No. 131 on information and monitoring. Journal of Accounting Research, 41 (2), 163-223.

Bernard, V.L., 1987. Cross-sectional dependence and problems in inference in market-based accounting research. Journal of Accounting Research, 25 (1), 1-48.

Bernard, V.L., 1995. The Feltham-Ohlson Framework: Implications for Empiricists. Contemporary Accounting Research, 11 (2), 733-747.

Bhattacharya, N., Black, E.L., Christensen, T.E., and Larson, C.R., 2003. Assessing the relative informativeness and permanence of pro forma earnings and GAAP operating earnings. Journal of Accounting and Economics, 36 (1), 285-319.

Bhattacharya, N., Desai, H., and Venkataraman, K., 2013. Does Earnings Quality Affect Information Asymmetry? Evidence from Trading Costs. Contemporary Accounting Research, 30 (2), 482-516. 
Blume, M.E., Lim, F., and MacKinlay, A.C., 1998. The declining credit quality of US corporate debt: Myth or reality? The Journal of Finance, 53 (4), 1389-1413.

Callen, J.L., Khan, M., and Lu, H., 2013. Accounting Quality, Stock Price Delay, and Future Stock Returns. Contemporary Accounting Research, 30 (1), 269-295.

Callen, J.L. and Segal, D., 2005. Empirical tests of the Feltham-Ohlson (1995) model. Review of Accounting Studies, 10 (4), 409-429.

Campbell, J.Y., Hilscher, J., and Szilagyi, J., 2008. In search of distress risk. The Journal of Finance, 63 (6), 2899-2939.

Dechow, P., Ge, W., and Schrand, C., 2010. Understanding earnings quality: A review of the proxies, their determinants and their consequences. Journal of Accounting and Economics, 50 (2), 344-401.

Dechow, P.M. and Dichev, I.D., 2002. The quality of accruals and earnings: The role of accrual estimation errors. The Accounting Review, 77 (s-1), 35-59.

Elliott, J.A. and Philbrick, D.R., 1990. Accounting changes and earnings predictability. The Accounting Review, 65 (1), 157-174.

Fairfield, P.M., Ramnath, S., and Yohn, T.L., 2009. Do Industry-Level Analyses Improve Forecasts of Financial Performance? Journal of Accounting Research, 47 (1), 147-178.

Fairfield, P.M., Sweeney, R.J., and Yohn, T.L., 1996. Accounting Classification and the Predictive Content of Earnings. The Accounting Review, 71 (3), 337-355.

Fairfield, P.M., Whisenant, J.S., and Yohn, T.L., 2003. Accrued earnings and growth: Implications for future profitability and market mispricing. The Accounting Review, 78 (1), 353-371.

Fairfield, P.M. and Yohn, T.L., 2001. Using asset turnover and profit margin to forecast changes in profitability. Review of Accounting Studies, 6 (4), 371-385.

Fama, E.F. and French, K.R., 2000. Forecasting Profitability and Earnings. The Journal of Business, 73 (2), 161-175.

Fama, E.F. and MacBeth, J.D., 1973. Risk, return, and equilibrium: Empirical tests. The Journal of Political Economy, 81 (3), 607-636.

Francis, J., LaFond, R., Olsson, P., and Schipper, K., 2004. Costs of Equity and Earnings Attributes. The Accounting Review, 79 (4), 967-1010.

Francis, J., Nanda, D., and Olsson, P., 2008. Voluntary disclosure, earnings quality, and cost of capital. Journal of Accounting Research, 46 (1), 53-99.

Francis, J. and Schipper, K., 1999. Have financial statements lost their relevance? Journal of Accounting Research, 37 (2), 319-352.

Jones, J., 1991. Earnings management during import relief investigations. Journal of Accounting Research, 29 (2), 193-228.

Kim, S., Kraft, P., and Ryan, S.G., 2013. Financial statement comparability and credit risk. Review of Accounting Studies, 18 (3), 783-823.

Lev, B., Li, S., and Sougiannis, T., 2010. The usefulness of accounting estimates for predicting cash flows and earnings. Review of Accounting Studies, 15 (4), 779-807.

Lev, B. and Thiagarajan, S.R., 1993. Fundamental information analysis. Journal of Accounting Research, 31 (2), 190-215. 
Lipe, R.C., 1986. The information contained in the components of earnings. Journal of Accounting Research, 24 (s), 37-64.

Lundholm, R. and Sloan, R., 2012. Equity Valuation and Analysis w/eVal. New York: McGraw-Hill/Irwin.

Mensah, Y.M., Song, X., and Ho, S.S., 2004. The effect of conservatism on analysts' annual earnings forecast accuracy and dispersion. Journal of Accounting, Auditing \& Finance, 19 (2), 159-183.

Mohanram, P.S., 2005. Separating Winners from Losers among LowBook-to-Market Stocks using Financial Statement Analysis. Review of Accounting Studies, 10 (2-3), 133-170.

Nekrasov, A. and Shroff, P.K., 2009. Fundamentals-based risk measurement in valuation. The Accounting Review, 84 (6), 1983-2011.

Newey, W. and Kenneth, W., 1987. A simple, positive, semi-definite, heteroscedasticity and autocorrelation consistent covariance matrix. Econometrica, 55 (3), 703-708.

Nissim, D. and Penman, S.H., 2001. Ratio analysis and equity valuation: From research to practice. Review of Accounting Studies, 6 (1), 109-154.

Ohlson, J., 1995. Earnings, book values, and dividends in equity valuation. Contemporary Accounting Research $11(2), 661-87$.

Ou, J.A., 1990. The information content of nonearnings accounting numbers as earnings predictors. Journal of Accounting Research, 28 (1), 144-163.

Ou, J.A. and Penman, S.H., 1989. Financial statement analysis and the prediction of stock returns. Journal of Accounting and Economics, 11 (4), 295-329.

Penman, S.H., 2010. Financial forecasting, risk and valuation: Accounting for the future. Abacus, 46 (2), $211-$ 228.

Penman, S.H., 2012. Financial statement analysis and security valuation. New York: McGraw-Hill.

Penman, S.H. and Zhang, X.-J., 2002. Accounting conservatism, the quality of earnings, and stock returns. The Accounting Review, 77 (2), 237-264.

Penman, S.H. and Zhang, X.-J., 2014. Connecting Book Rate of Return to Risk: The Information Conveyed by Conservative Accounting. Working Paper, Columbia Business School Research Paper.

Piotroski, J.D. and So, E.C., 2012. Identifying expectation errors in value/glamour strategies: A fundamental analysis approach. Review of Financial Studies, 25 (9), 2842-2875.

Poon, S.-H. and Granger, C.W., 2003. Forecasting volatility in financial markets: A review. Journal of Economic Literature, 41 (2), 478-539.

Rajan, M.V., Reichelstein, S., and Soliman, M.T., 2007. Conservatism, growth, and return on investment. Review of Accounting Studies, 12 (2-3), 325-370.

Raman, K., Shivakumar, L., and Tamayo, A., 2013. Target's earnings quality and bidders' takeover decisions. Review of Accounting Studies, 18 (4), 1050-1087.

Revsine, L., Collins, D.W., Johnson, W.B., Collins, D.W., and Johnson, W.B., 2005. Financial Reporting \& Analysis. New York: Pearson/Prentice Hall.

Setiono, B. and Strong, N., 1998. Predicting stock returns using financial statement information. Journal of Business Finance \& Accounting, 25 (5-6), 631-657.

Sloan, R.G., 1996. Do stock prices fully reflect information in accruals and cash flows about future earnings? The Accounting Review, 71 (3), 289-315. 
Soliman, M.T., 2008. The use of DuPont analysis by market participants. The Accounting Review, 83 (3), $823-$ 853.

Tucker, J.W. and Zarowin, P.A., 2006. Does income smoothing improve earnings informativeness? The Accounting Review, 81 (1), 251-270.

Vuong, Q.H., 1989. Likelihood ratio tests for model selection and non-nested hypotheses. Econometrica: Journal of the Econometric Society, 57 (2), 307-333.

Xie, H., 2001. The mispricing of abnormal accruals. The Accounting Review, 76 (3), 357-373. 


\section{Appendix 1}

Variable definitions

\begin{tabular}{|c|c|c|}
\hline Variable & Description & Computation \\
\hline$C E Q_{t}$ & Common equity & \\
\hline $\mathrm{CHE}_{t}$ & Cash and short-term investments & \\
\hline$D L C_{t}$ & Debt in current liabilities & \\
\hline$D L T T_{t}$ & Long-term debt & \\
\hline$D O_{t}$ & Discontinued operations & \\
\hline$D V P_{t}$ & Dividends preferred & \\
\hline$D V P A_{t}$ & Dividends preferred in arrears & \\
\hline$I D I T_{t}$ & Interest and related income & \\
\hline$I V A O_{t}$ & Other investments and advances & \\
\hline$L I F R_{t}$ & LIFO reserves & \\
\hline$N I_{t}$ & Net income & \\
\hline PSTK $_{t}$ & Preferred stock & \\
\hline$R E V T_{t}$ & Revenues & \\
\hline$T X T_{t}$ & Income taxes & \\
\hline $\operatorname{TSTKP}_{t}$ & Preferred treasury stock & \\
\hline$X A D_{t}$ & Advertising expenses & \\
\hline$X R D_{t}$ & Research and developement expenses & \\
\hline$C S E_{t}$ & Common shareholders' equity & $C E Q_{t}+T S T K P_{t}-D V P A_{t}$ \\
\hline$F A_{t}$ & Financial assets & $C H E_{t}+I V A O_{t}$ \\
\hline$F O_{t}$ & Financial obligations & $\begin{array}{l}D L C_{t}+D L T T_{t}+P S T K_{t}-\operatorname{TSTKP}_{t} \\
+D V P A_{t}\end{array}$ \\
\hline$N F E_{t}$ & Net financial expenses & $-\left(I D I T_{t}-X I N T_{t}-D V P_{t}\right)$ \\
\hline$N F O_{t}$ & Net financial assets & $F O_{t}-F A_{t}$ \\
\hline$N^{\prime B B T} t_{t}$ & Net income before taxes & $N I_{t}+T X T_{t}-D V P_{t}-D O_{t}$ \\
\hline$N O A_{t}$ & Net operating assets & $F O_{t}-F A_{t}+C S E_{t}$ \\
\hline $\mathrm{NOI}_{t}$ & Net operating income & $N I B T_{t}+N F E_{t}$ \\
\hline$A N F O_{t}$ & Average net financial obligations & $\left(N F O_{t}+N F O_{t-1}\right) / 2$ \\
\hline $\mathrm{ANOA}_{t}$ & Average net operating assets & $\left(N O A_{t}+N O A_{t-1}\right) / 2$ \\
\hline$A T O_{t}$ & Asset turnover & $R E V T_{t} / A N O A_{t}$ \\
\hline$B V E_{t}$ & Average common shareholders' equity & $\left(C S E_{t}+C S E_{t-1}\right) / 2$ \\
\hline$L E V_{t}$ & Leverage & $A N F O_{t} / B V E_{t}$ \\
\hline$N B C_{t}$ & Net borrowing costs & $N F E_{t} / A N F O_{t}$ \\
\hline$P M_{t}$ & Profit margin & $\mathrm{NOI}_{t} / \mathrm{REVT} \mathrm{T}_{t}$ \\
\hline $\mathrm{RNOA}_{t}$ & Return on net operating assets & $\mathrm{NOI}_{t} / \mathrm{ANOA}_{t}$ \\
\hline$\triangle A T O_{t}$ & Change in asset turnover & $\left(\left(A T O_{t}-A T O_{t-1}\right) / A T O_{t-1}\right) \times P M_{t-1}$ \\
\hline$\Delta I N T_{t}$ & $\begin{array}{l}\text { Interaction between change in asset turnover } \\
\text { and change in profit margin }\end{array}$ & $\Delta A T O_{t} x \Delta P M_{t}$ \\
\hline$\triangle N O A_{t}$ & Change in net operating assets & $\left(N O A_{t}-N O A_{t-1}\right) / N O A_{t-1}$ \\
\hline$\Delta P M_{t}$ & Change in profit margin & $\left(\left(P M_{t}-P M_{t-1}\right) / P M_{t-1}\right) x A T O_{t-1}$ \\
\hline$\triangle R N O A_{t}$ & Change in return on net operating assets & $\left(R N O A_{t}-R N O A_{-1}\right) / R N O A_{t-1}$ \\
\hline
\end{tabular}




\section{Diskussionsbeiträge - Fachbereich Wirtschaftswissenschaft - Freie Universität Berlin Discussion Paper - School of Business and Economics - Freie Universität Berlin}

2015 erschienen:

2015/1 GÖRLITZ, Katja und Christina GRAVERT

The effects of increasing the standards of the high school curriculum on school dropout

Economics

2015/2 BÖNKE, Timm und Clive WERDT

Charitable giving and its persistent and transitory reactions to changes in tax incentives: evidence from the German Taxpayer Panel

Economics

2015/3 WERDT, Clive

What drives tax refund maximization from inter-temporal loss usage? Evidence from the German Taxpayer Panel

Economics

2015/4 FOSSEN, Frank M. und Johannes KÖNIG

Public health insurance and entry into self-employment

Economics

2015/5 WERDT, Clive

The elasticity of taxable income for Germany and its sensitivity to the appropriate model

Economics

2015/6 NIKODINOSKA, Dragana und Carsten SCHRÖDER

On the Emissions-Inequality Trade-off in Energy Taxation: Evidence on the German Car Fuel Tax

Economics

2015/7 GROß, Marcus; Ulrich RENDTEL; Timo SCHMID; Sebastian SCHMON und Nikos TZAVIDIS

Estimating the density of ethnic minorities and aged people in Berlin: Multivariate kernel density estimation applied to sensitive geo-referenced administrative data protected via measurement error

Economics

2015/8 SCHMID, Timo; Nikos TZAVIDIS; Ralf MÜNNICH und Ray CHAMBERS

Outlier robust small area estimation under spatial correlation

Economics

2015/9 GÖRLITZ, Katja und Marcus TAMM

Parenthood and risk preferences

Economics

2015/10 BÖNKE, Timm; Giacomo CORNEO und Christian WESTERMEIER

Erbschaft und Eigenleistung im Vermögen der Deutschen: eine Verteilungsanalyse Economics 
2015/11 GÖRLITZ, Katja und Marcus TAMM

The pecuniary and non-pecuinary returns to voucher-financed training

Economics

2015/12 CORNEO, Giacomo

Volkswirtschaftliche Bewertung öffentlicher Investitionen

Economics

2015/13 GÖRLITZ, Katja und Christina Gravert

The effects of a high school curriculum reform on university enrollment and the choice of college major

Economics

2015/14 BÖNKE, Timm und Carsten SCHRÖDER

European-wide inequality in times of the financial crisis

Economics

2015/15 BÖNKE, Timm; Beate JOACHIMSEN und Carsten SCHRÖDER

Fiscal federalism and tax enforcement

Economics 